\title{
Gall-inducing insects of an Araucaria Forest in southern Brazil
}

\author{
Tiago Shizen Pacheco Toma ${ }^{1} \&$ Milton de Souza Mendonça Júnior ${ }^{2}$
}

${ }^{1}$ PPG - Ecologia, Universidade Federal do Rio Grande do Sul, Av. Bento Gonçalves 9500 Bloco IV, 91501-970 Porto Alegre-RS. tiagoshizen@gmail.com ${ }^{2}$ Departamento de Ecologia, Universidade Federal do Rio Grande do Sul, Av. Bento Gonçalves 9500 Bloco IV, 91501-970 Porto Alegre-RS. milton.mendonca@ufrgs.br

\begin{abstract}
Gall-inducing insects of an Araucaria Forest in southern Brazil. Diversity of galling insects is reported for the first time in an Araucaria Forest site. We address gall characteristics, host plant identification and the inducer identification and provide additional information about sites of gall occurrence in a mosaic of continuous forest and natural forest patches. After $40 \mathrm{~h}$ of sampling we found 57 species of five insect orders, the majority of them Diptera (Cecidomyiidae), galling 43 host plant species, which in turn belonged to 18 host plant families. Stem and buds together, compared to leaves, harbored more galls, which were mostly glabrous, isolated, fusiform and green. Myrtaceae, Asteraceae and Melastomataceae were the most representative host families. Similarities in gall characteristics to what has been reported in the literature probably result from spatial correlation in a larger scale driven by ecological and evolutionary processes.
\end{abstract}

KEYWORDS. Diversity; forest patch; host plant; insect galls; Insecta.

Galls are the result of an abnormal growth induced on plants by different organisms, most of them insects, such as Diptera, Hymenoptera and Coleoptera (Mani 1964; DregerJauffret \& Shorthouse 1992; Shorthouse et al. 2005). The formation of a gall is essential to the inducers and is part of their life cycle, most of them being host-specific, especially those belonging to the dipteran family Cecidomyiidae (Shorthouse et al. 2005; Carneiro et al. 2009a).

Gall inventories in Brazil increased in number in the last decades, and most biomes of the country were surveyed at least once (Santos et al. 2011 and references therein). However, due to the concentration of taxonomists and research groups, most surveys were conducted at sites in southeastern Brazil, including areas under cerrado (e.g., Fernandes et al. 1988; Gonçalves-Alvim \& Fernandes 2001; UrsoGuimaraes \& Scarelli-Santos 2006), Atlantic forest (e.g., Fernandes et al. 2001; Moreira et al. 2007) and specific ecosystems within these biomes (e.g., rupestrian fields, Maia \& Fernandes 2004; Carneiro et al. 2009b, and restinga, Oliveira \& Maia 2005; Maia et al. 2008).

In southern Brazil the first studies on gall-inducing insects were conducted by Tavares $(1906,1909)$ and Kieffer (1913), and since then they have been sparse. Lately, there were studies on the diversity of subtropical forests of the region (Dalbem \& Mendonça 2006; Mendonça 2007; Mendonça et al. 2010) with a single new gall-midge genus and two species described from there (Maia et al. 1996; Maia et al. 2009). Despite the Araucaria forest being a relatively well-studied and very characteristic landscape (Ribeiro et al. 2009), its galling insect fauna remains unknown. Araucaria forest is a formation within the South American Atlantic forests, extending its domain several kilometers into the continent (Oliveira-Filho \& Fontes 2000). As with all Atlantic forests, plant and animal richness is high, with the biogeographic value of the vegetation residing in its defining canopy species Araucaria angustifolia, a conifer that dominates the landscape and gives a temperate character to a mainly tropical biota (Oliveira-Filho \& Fontes 2000). At higher altitudes there is a marked presence of Campos grasslands forming mosaics with Araucaria forests, with forests tending to expand over grasslands under conditions of fire and grazing exclusion (Oliveira \& Pillar 2004). We report for the first time the diversity of galling insects in an Araucaria Forest site, addressing gall morphological characteristics, host plant and inducer identification, investigating the occurrence of galls within both continuous stands of Araucaria forest and smaller natural forest patches surrounded by grasslands.

\section{MATERIAL AND METHODS}

Study site. This research was carried out in the Pró-Mata Research and Nature Conservation Center (29 $28^{\prime} \mathrm{S}$, $50^{\circ} 13^{\prime} \mathrm{W}$, henceforth $\mathrm{PM}$ ) and two farms at the PM vicinity (Três Estrelas Farm 29²8'08'S, 50¹2'38"W, TE; and Três Cachoeiras Farm, 29²6’21"S, 50¹6’21"W, TC), all located at the municipality of São Francisco de Paula, Rio Grande do Sul State, southern Brazil. The study sites are located on a plateau at ca. $900 \mathrm{~m}$ a.s.l. with vegetation characterized by Campos grassland and Araucaria forest. PM has no cattle grazing or burning practices since 1994, a singular situation in the region, but still commonly practiced in the nearby farms. Hence, forests have been regenerating in the former (Oliveira \& Pillar 2004) while management practices are still adopted constantly in the latter farms. The regional climate is classified according to Köppen as Cfb (Moreno 1961), which is a subtropical rainy climate, with a uniformly dis- 
tributed precipitation throughout the year, and warm summers. The annual mean temperature is $15^{\circ} \mathrm{C}$, and annual mean rainfall is $2086 \mathrm{~mm}$ (Hijmans et al. 2005).

Sampling galling insects. We focused on sampling the existing forests in the landscape (forest types), distinguishing between a large forested area, here called 'continuous forest', and smaller 'natural forest patches' inserted in the grasslands. This was performed in order to account for possible differences since forest patches exhibit their own dynamics of expansion over grasslands (Oliveira \& Pillar 2004). Sampling was carried out in five occasions cumulatively: December 2010, and April, May, June and September 2011; given the absence of seasonality for the gallers of this region (Dalbem \& Mendonça 2006) and the sampling of both forest types in each occasion, gall seasonality is not expected to affect the results. Five sampling sites for each forest type were in a recovering area (PM) and five were in disturbed areas (three at TC and two at TE), totalizing ten sampling sites per forest type. For continuous forests, we considered portions of the forest adjacent to the grassland at least $500 \mathrm{~m}$ apart to guarantee independence. Forest patches were relatively small forest formations surrounded by grasslands ranging in size from 0.06 to 0.56 ha.

At each site we took one sample at the edge and one at the interior. In this study, we defined edge as the transition between the trees and grassland, following an imaginary line connecting the plant individuals over $2 \mathrm{~m}$ tall that touched the crown of at least another such plant. In order to standardize the samples in terms of range inspected at the interior for each forest type, these samples were restricted to a strip until $25 \mathrm{~m}$ away from the edge transect inspected on continuous forest portions, while at forest patches, they were situated at the center of the patch. We confirmed the difference between edge and interior in temperature and humidity during the day for some representative sites (data not shown).

Each sample was obtained in $60 \mathrm{~min}$ surveys actively searching for galls along the border of the entire forest patch for the edge samples or in short linear transects through the interior, following the methodology proposed by Julião et al. (2004). In their study, Julião et al. (2004) sampled structurally similar forest patches in Pantanal. Our total sampling effort was $40 \mathrm{~h}$. During the sampling period we collected galls and plant branches for identification of inducers and their hosts. Galls were separated in morphotypes (from now on called species; see Carneiro et al. 2009a) and later dissected under stereomicroscope. Galls were also placed in plastic pots to rear adult insects. Gall inducers were identified down to the lowest taxonomic level possible, including the help of specialists on each group when available.

\section{RESULTS}

We found 57 galling insect species from five insect orders, of which 14 remained undetermined. Galls occurred on 43 host plant species, belonging to 18 host families (Table I, Figs. $1-3)$. Most galls were induced by species of Diptera, all be- longing to the family Cecidomyiidae (54.4\%), followed by Lepidoptera (8.8\%), Hemiptera (7.0\%), Thysanoptera (3.5\%) and Coleoptera (1.7\%), and unidentified inducers (24.6\%). The galls were induced almost equally on leaves $(36.8 \%)$ and stems (33.3\%), but also buds (28.1\%), and on both leaves and stems $(1.7 \%)$. Galls were mostly glabrous $(78.9 \%)$ and occurred isolated from one another $(80.7 \%)$. The most common shape was fusiform $(43.9 \%)$, followed by globoid $(26.3 \%)$, discoid $(12.3 \%)$, conical $(8.8 \%)$, cylindrical $(5.3 \%)$ and amorphous (3.4\%). The majority of galls were green $(70.2 \%)$.

The most representative host plant families were Myrtaceae, with 20 gall morphotypes (35.0\%), Asteraceae, with eight (14.0\%), and Melastomataceae, with five (8.7\%), totaling more than one half of all morphotypes $(57.7 \%)$. The same families had the highest number of host plant species, $12(27.9 \%)$, eight (18.6\%) and four (9.3\%), respectively, likewise comprising together more than one half of all host plant species $(55.8 \%)$. The most representative genera in number of gall morphotypes were Myrcia, with seven (12.3\%), Myrceugenia, with six (10.5\%), and Siphoneugena, with four (7.0\%), all three belonging to Myrtaceae. The host plant species that harbored more gall morphotypes were Siphoneugena reitzii, with four, and Myrcia guianensis and Ilex microdonta, with three morphotypes each.

Overall, 39 galling insect species occurred at the edge and 37 in the interior of forests, 19 occurring on both habitats (Table I). Recovering sites had 43 species, while disturbed ones had 31, with 17 common to both types. Portions of continuous forests had together 49 species, while forest patches totalized 33 and 25 occurred on both recovering and disturbed sites (Fig. 4A). Regarding the host plants: 30 were at the edge and 26 in the interior, with 13 species common to both habitats; 38 were in continuous forests and 23 in forest patches, with 18 in common to both forest types; 33 were in recovering sites and 24 in disturbed ones, with 14 in common to them (Fig. 4B).

\section{DISCUSSION}

The total richness of galling insects found here (57) can be classified as intermediate considering the richness found by Araújo et al. (2011; 62 galling species) who themselves were comparing their result to other studies in terms of crude numbers. However it is important to account for differences among the studies, at least in terms of sampling effort. For instance, in a terra firme Amazon forest 309 gall morphotypes were recorded in $216 \mathrm{~h}$ of sampling (Almada \& Fernandes 2011), and in natural forest patches of the Pantanal biome 133 gall morphotypes were recorded in $54 \mathrm{~h}$ of sampling (Julião et al. 2004). Other issues may also interfere and direct comparisons are certainly tentative, but scale is a likely factor influencing richness in gall surveys. Our samples, alternatively, were obtained in a more restricted area with the galling fauna of forest patches representing either subsets of the continuous forest or being very similar to them (Toma \& Mendonça, unpubl.). 

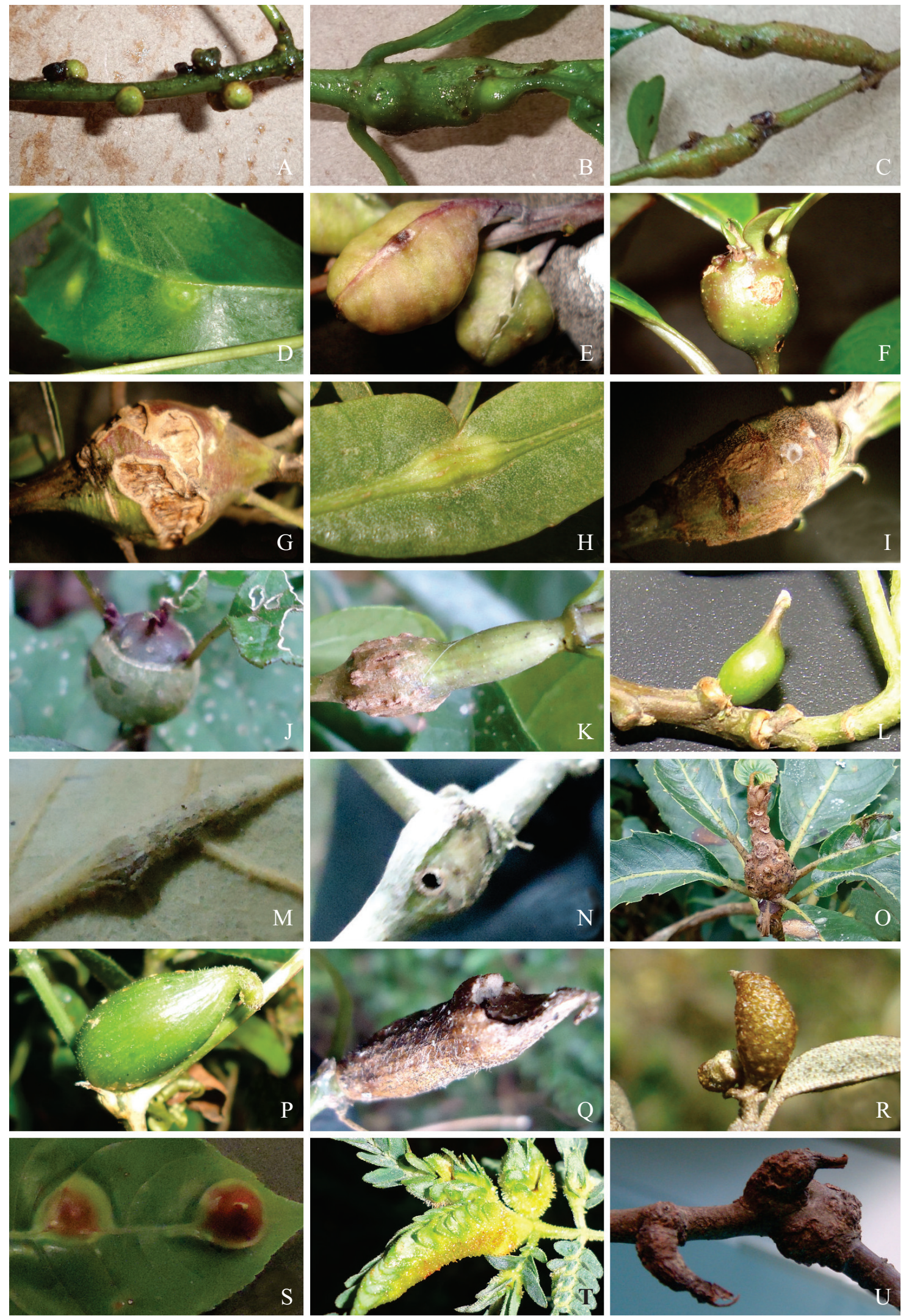

Fig. 1. Galling insect morphotypes of an Araucaria Forest site in southern Brazil. A-B) Chamissoa altissima (Amaranthaceae), C) Lithraea brasiliensis (Anacardiaceae), D-F) Ilex microdonta (Aquifoliaceae), G) Baccharis semiserrata (Asteraceae), H) Baccharis sp. (Asteraceae), I) Eupatorium serratum (Asteraceae), J) Mikania campanulata (Asteraceae), K) Mikania paranensis (Asteraceae), L) Pentacalia desiderabilis (Asteraceae), M) Piptocarpha axillaris (Asteraceae), N) Piptocarpha notata (Asteraceae), O) Clethra uleana (Clethraceae), P) Cayaponia sp. 1 (Curcubitaceae), Q) Cayaponia sp. 2 (Curcubitaceae), R) Croton sp. (Euphorbiaceae), S) Sapium glandulosum (Euphorbiaceae), T) Mimosa scabrella (Fabaceae), U) Nectandra grandiflora (Lauraceae). 

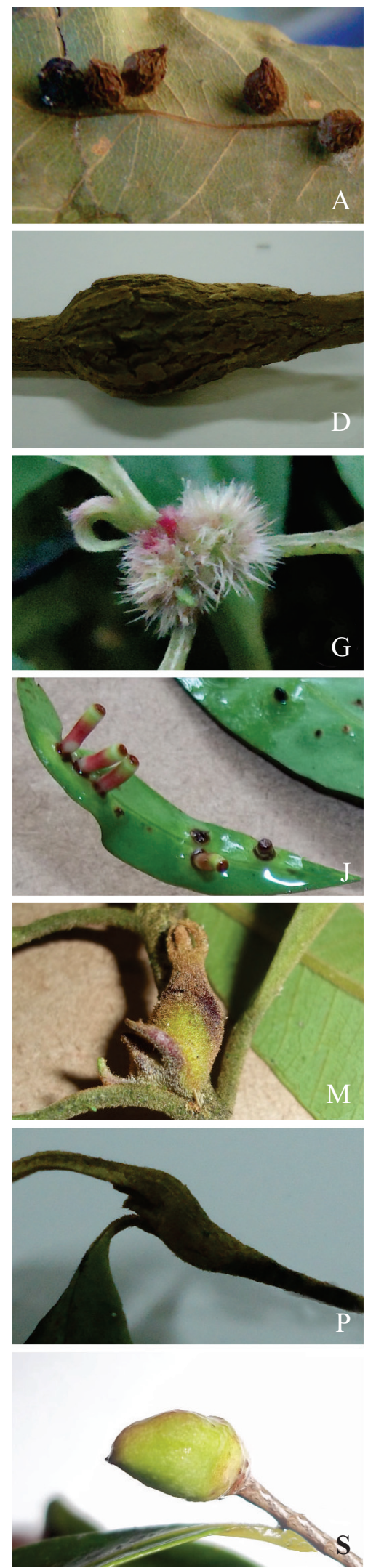
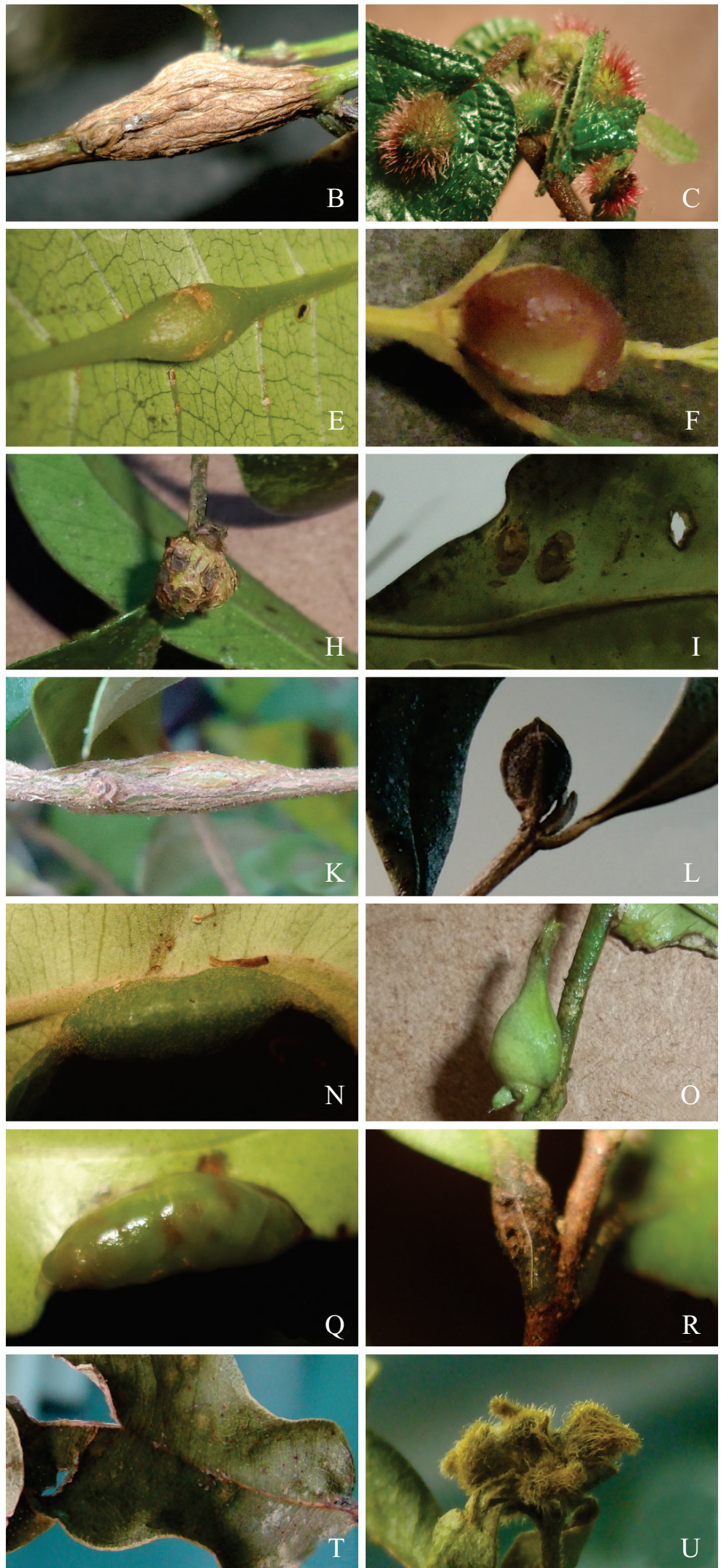

Fig. 2. Galling insect morphotypes of an Araucaria Forest site in southern Brazil. A-B) Ocotea corymbosa (Lauraceae), C) Leandra sp. (Melastomataceae), D) Miconia hyemalis (Melastomataceae), E) Miconia pusilliflora (Melastomataceae), F-G) Tibouchina sellowiana (Melastomataceae), H-I) Calyptranthes concinna (Myrtaceae), J) Eugenia pluriflora (Myrtaceae), K) Myrceugenia euosma (Myrtaceae), L) Myrceugenia mesomischa (Myrtaceae), M) Myrceugenia miersiana (Myrtaceae), N-O) Myrceugenia myrcioides (Myrtaceae), P) Myrcengenia oxysepala (Myrtaceae), Q-S) Myrcia guianensis (Myrtaceae), T-U) Myrcia hartwegiana (Myrtaceae). 

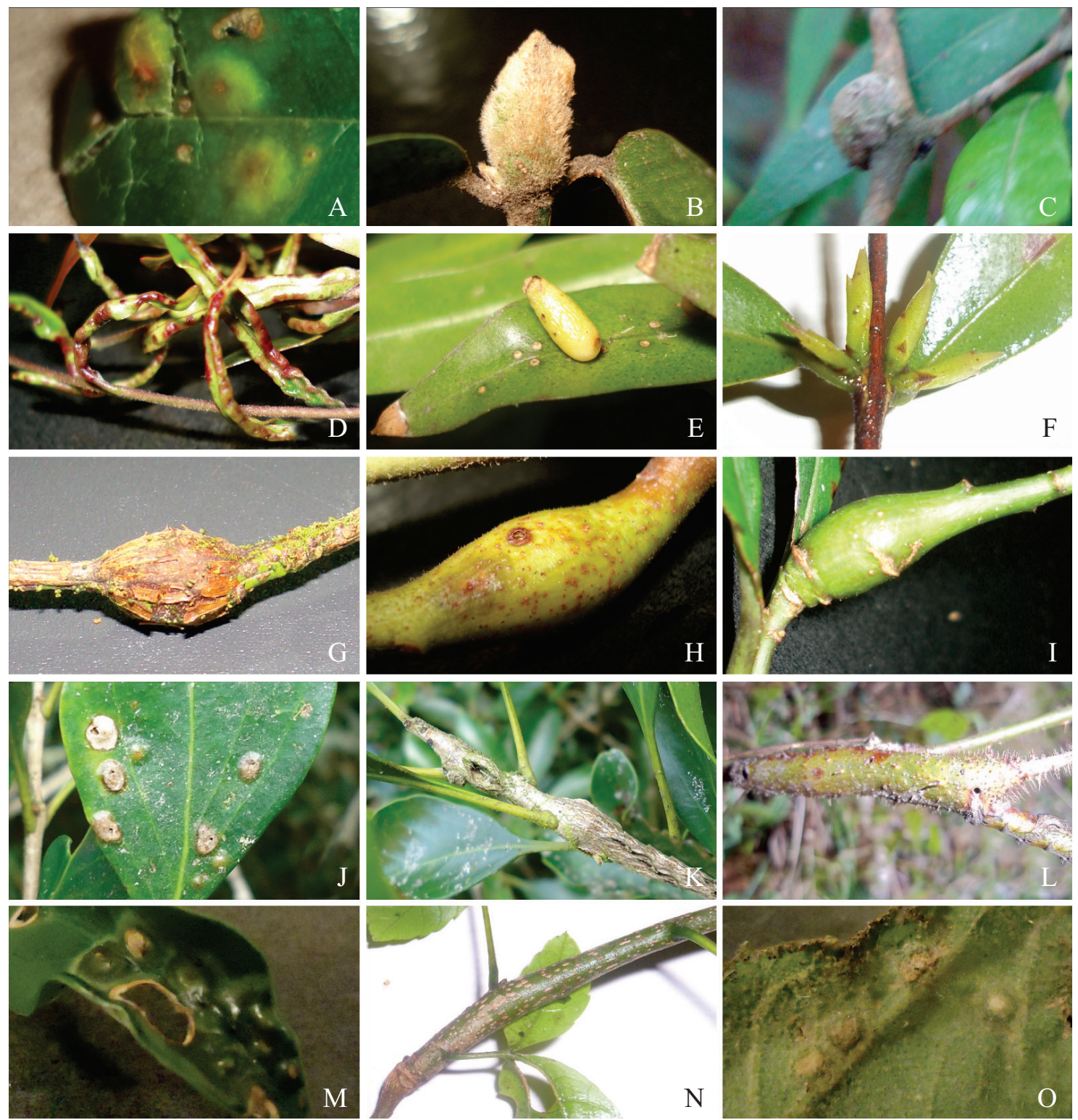

Fig. 3. Galling insect morphotypes of an Araucaria Forest site in southern Brazil. A) Myrcia palustris (Myrtaceae), B) Myrcia retorta (Myrtaceae), C-F) Siphoneugena reitzii (Myrtaceae), G) Podocarpus lambertii (Podocarpaceae), H) Myrsine coriacea (Primulaceae), I) Myrsine lorentziana (Primulaceae), J-K) Roupala montana (Proteaceae), L) Rubus erythrocladus (Rosaceae), M) Rudgea parquioides (Rubiaceae), N) Allophylus edulis (Sapindaceae) (photography by Cristina R. Wenzel), O) Solanum sp. (Solanaceae).

The most representative taxon of gall inducers was the dipteran family Cecidomyiidae, a pattern common to other ecosystems worldwide (Espírito-Santo \& Fernandes 2007). This might be expected given that the family Cecidomyiidae is the most speciose group of gall-inducing insects (Gagné 2010). The other taxa observed here also appear in many studies, but with clear differences between regions (Mani 1964; Espírito-Santo \& Fernandes 2007). Additionally, most likely our study is the first one in Brazil to present detailed identification of Thysanoptera gall inducers, which are probably new species. It is important to stress that unidentified gallers were mostly from rare plants with few galls, which in turn were either open or attacked by parasitoids.
A strong predominance for leaves was not observed here in regard to galled organs, with galls evenly distributed among plant organs. This trend is uncommon for insect galls, which are usually reported to occur predominantly on leaves (DregerJauffret \& Shorthouse 1992; Fernandes et al. 1988; Maia \& Fernandes 2004; Moreira et al. 2007; Maia et al. 2008). Only a few studies report more galls on stems (African savanna; Veldtman \& McGeoch 2003) or stems and buds (rupestrian fields; Carneiro et al. 2009b). Interestingly, these studies were performed on areas geographically related to the Araucaria forest, either in terms of altitude (Carneiro et al. 2009b) or southern location (Veldtman \& McGeoch 2003). However, their explanations, despite being valuable, did not account for this 
Table I. Galling insect species and host plants of an Araucaria Forest site in southern Brazil. Host plants, gall morphology, gall maker and sites of occurrence (numbers represent sum of occurrences for the combination of factors, 10 is the maximum value).

\begin{tabular}{|c|c|c|c|c|c|c|c|c|c|c|}
\hline \multirow{3}{*}{ Host plant } & \multicolumn{3}{|c|}{ Gall morphology } & \multirow{3}{*}{ Gall inducer } & \multicolumn{5}{|c|}{ Site of occurrence } & \multirow{3}{*}{ Figure } \\
\hline & \multirow[t]{2}{*}{ Organ } & \multirow[t]{2}{*}{ Shape } & \multirow[t]{2}{*}{ Color } & & \multicolumn{2}{|c|}{ Recovering } & \multicolumn{3}{|c|}{ Disturbed } & \\
\hline & & & & & Edge & Interior & Edge & Interior & Total & \\
\hline \multicolumn{11}{|l|}{ Amaranthaceae } \\
\hline \multirow[t]{2}{*}{ Chamissoa altissima (Jacq.) Kunth } & stem & globoid & green & Cecidomyiidae & & $1^{\mathrm{P}}$ & $1^{\mathrm{F}}$ & 6 & 8 & $1 \mathrm{~A}$ \\
\hline & leaf/stem & amorphous $^{1,2}$ & green & Clinodiplosis sp. (Cecidomyiidae) & $1^{\mathrm{P}}$ & 2 & 6 & 10 & 19 & 1B \\
\hline \multicolumn{11}{|l|}{ Anacardiaceae } \\
\hline Lithraea brasiliensis Marchand & stem & fusiform ${ }^{2}$ & brown & Unidentified & & & & $1^{\mathrm{P}}$ & 1 & $1 \mathrm{C}$ \\
\hline \multicolumn{11}{|l|}{ Aquifoliaceae } \\
\hline \multirow[t]{3}{*}{ Ilex microdonta Reissek } & leaf & discoid & green & Cecidomyiidae & 6 & $4^{\mathrm{P}}$ & & & 10 & $1 \mathrm{D}$ \\
\hline & leaf & globoid & green & Hemiptera & 3 & & $1^{\mathrm{F}}$ & & 4 & $1 \mathrm{E}$ \\
\hline & bud & globoid & green & Cecidomyiidae & 5 & 8 & $1^{\mathrm{F}}$ & $2^{P}$ & 16 & $1 \mathrm{~F}$ \\
\hline \multicolumn{11}{|l|}{ Asteraceae } \\
\hline Baccharis semiserrata DC. & stem & globoid & green/brown & Unidentified & $1^{\mathrm{P}}$ & & & & 1 & $1 \mathrm{G}$ \\
\hline Baccharis sp. & stem & fusiform $^{2}$ & green & Alycaulini (Cecidomyiidae) & 3 & & 8 & & 11 & $1 \mathrm{H}$ \\
\hline Eupatorium serratum Spreng. & stem & fusiform & green/brown & Unidentified & $1^{\mathrm{F}}$ & & & & 1 & $1 \mathrm{I}$ \\
\hline Mikania campanulata Gardner & bud & globoid $^{2}$ & green/purple & Contarinia sp. (Cecidomyiidae) & $1^{\mathrm{F}}$ & & & & 1 & $1 \mathrm{~J}$ \\
\hline Mikania paranensis Dusén & stem & fusiform & green & Cecidomyiidae & $1^{\mathrm{F}}$ & & & & 1 & $1 \mathrm{~K}$ \\
\hline Pentacalia desiderabilis (Vell.) Cuatrec. & bud & conical & green & Asphondylia sp. (Cecidomyiidae) & & & $1^{\mathrm{F}}$ & & 1 & $1 \mathrm{~L}$ \\
\hline Piptocarpha axillaris (Less.) Baker & leaf (rib) & fusiform ${ }^{1}$ & brown & Unidentified & $2^{\mathrm{F}}$ & & & & 2 & $1 \mathrm{M}$ \\
\hline Piptocarpha notata (Less.) Baker & stem & globoid & green & Resseliella sp. (Cecidomyiidae) & $1^{\mathrm{F}}$ & $3^{\mathrm{F}}$ & & & 4 & $1 \mathrm{~N}$ \\
\hline \multicolumn{11}{|l|}{ Clethraceae } \\
\hline Clethra uleana Sleumer & bud & globoid & brown & Cecidomyiidae & 2 & & & & 2 & 10 \\
\hline Curcubitaceae & & & & & & & & & & \\
\hline Cayaponia sp. 1 & bud & fusiform ${ }^{1}$ & green & Coleoptera & $1^{\mathrm{F}}$ & & & & 1 & $1 \mathrm{P}$ \\
\hline Cayaponia sp. 2 & bud & fusiform ${ }^{1}$ & brown & Lepidoptera & $1^{\mathrm{F}}$ & & & & 1 & 1Q \\
\hline Euphorbiaceae & & & & & & & & & & \\
\hline Croton sp. & bud & globoid & brown & Cecidomyiidae & $2^{\mathrm{F}}$ & & & & 2 & $1 \mathrm{R}$ \\
\hline Sapium glandulosum (L.) Morong & leaf & conical & red & Psyllidae (Hemiptera) & 3 & $1^{\mathrm{P}}$ & & & 4 & $1 \mathrm{~S}$ \\
\hline Fabaceae & & & & & & & & & & \\
\hline Mimosa scabrella Benth. & leaf & amorphous $^{1,2}$ & orange & Cecidomyiidae & $1^{\mathrm{F}}$ & & & & 1 & $1 \mathrm{~T}$ \\
\hline Lauraceae & & & & & & & & & & \\
\hline Nectandra grandiflora Nees & stem & fusiform ${ }^{2}$ & brown & Unidentified & & $1^{\mathrm{F}}$ & & & 1 & $1 \mathrm{U}$ \\
\hline Ocotea corymbosa (Meisn.) Mez & leaf & conical & brown & Unidentified & & $1^{\mathrm{F}}$ & & & 1 & $2 \mathrm{~A}$ \\
\hline & stem & fusiform & brown & Unidentified & & $1^{\mathrm{F}}$ & & & 1 & $2 \mathrm{~B}$ \\
\hline Melastomataceae & & & & & & & & & & \\
\hline Leandra sp. & leaf & globoid $^{1}$ & green & Cecidomyiidae & & $2^{\mathrm{F}}$ & & $1^{\mathrm{F}}$ & 3 & $2 \mathrm{C}$ \\
\hline Miconia hyemalis A.St.-Hil. \& Naudin & stem & fusiform & brown & Unidentified & & & $1^{\mathrm{F}}$ & & 1 & $2 \mathrm{D}$ \\
\hline Miconia pusilliflora (DC.) Naudin & leaf (rib) & fusiform & green & Cecidomyiidae & & $1^{\mathrm{P}}$ & & & 1 & $2 \mathrm{E}$ \\
\hline Tibouchina sellowiana Cogn. & stem & globoid & green/red & Gelechioidea (Lepidoptera) & 5 & & $1^{\mathrm{P}}$ & $1^{\mathrm{F}}$ & 7 & $2 \mathrm{~F}$ \\
\hline & leaf/petiole & globoid $^{1}$ & green/red & Lopesia sp. (Cecidomyiidae) & 5 & $1^{\mathrm{F}}$ & $1^{\mathrm{P}}$ & 3 & 10 & $2 \mathrm{G}$ \\
\hline Myrtaceae & & & & & & & & & & \\
\hline Calyptranthes concinna DC. & bud & globoid $^{2}$ & green & Lasiopteridi (Cecidomyiidae) & & & 4 & 6 & 10 & $2 \mathrm{H}$ \\
\hline & leaf & discoid & green/brown & Cecidomyiidae & & & $1^{\mathrm{P}}$ & $1^{\mathrm{F}}$ & 2 & 2I \\
\hline Eugenia pluriflora DC. & leaf & cylindrical & green/red & Stephomyia sp. (Cecidomyiidae) & & & & $2^{\mathrm{F}}$ & 2 & $2 \mathrm{~J}$ \\
\hline $\begin{array}{l}\text { Myrceugenia euosma (O.Berg) } \\
\text { D.Legrand }\end{array}$ & stem & fusiform $^{2}$ & brown & Cecidomyiidae & 8 & & 10 & 5 & 23 & $2 \mathrm{~K}$ \\
\hline $\begin{array}{l}\text { Myrceugenia mesomischa (Burret) } \\
\text { D.Legrand \& Kausel }\end{array}$ & bud & conical & green & Unidentified & & & $1^{\mathrm{F}}$ & & 1 & $2 \mathrm{~L}$ \\
\hline $\begin{array}{l}\text { Myrceugenia miersiana (Gardner) } \\
\text { D.Legrand \& Kausel }\end{array}$ & bud & fusiform ${ }^{1}$ & green/purple & Cecidomyiidae & & & & 2 & 2 & $2 \mathrm{M}$ \\
\hline $\begin{array}{l}\text { Myrceugenia myrcioides (Cambess.) } \\
\text { O.Berg }\end{array}$ & leaf & fusiform & green & Unidentified & & $1^{\mathrm{P}}$ & & & 1 & $2 \mathrm{~N}$ \\
\hline & bud & fusiform & green & Cecidomyiidae & & & & $1^{\mathrm{F}}$ & 1 & $2 \mathrm{O}$ \\
\hline $\begin{array}{l}\text { Myrceugenia oxysepala (Burret) } \\
\text { D.Legrand \& Kausel }\end{array}$ & bud & fusiform & brown & Clinodiplosis sp. (Cecidomyiidae) & & $1^{\mathrm{F}}$ & & & 1 & $2 \mathrm{P}$ \\
\hline Myrcia guianensis (Aubl.) DC. & leaf & fusiform & green/red & Holopothrips sp. (Thysanoptera) & $2^{\mathrm{P}}$ & & $1^{\mathrm{P}}$ & $1^{\mathrm{F}}$ & 4 & $2 \mathrm{Q}$ \\
\hline & leaf (petiole) & fusiform & green & Cecidomyiidae & & 2 & & & 2 & $2 \mathrm{R}$ \\
\hline & bud & globoid & green/red & Cecidomyiidae & 2 & $1^{\mathrm{F}}$ & 3 & 3 & 9 & $2 \mathrm{~S}$ \\
\hline
\end{tabular}


Table I. Continued.

\begin{tabular}{|c|c|c|c|c|c|c|c|c|c|c|}
\hline \multirow{3}{*}{ Host plant } & \multicolumn{3}{|c|}{ Gall morphology } & \multirow{3}{*}{ Gall inducer } & \multicolumn{5}{|c|}{ Site of occurrence } & \multirow{3}{*}{ Figure } \\
\hline & \multirow[t]{2}{*}{ Organ } & \multirow[t]{2}{*}{ Shape } & \multirow[t]{2}{*}{ Color } & & \multicolumn{2}{|c|}{ Recovering } & \multicolumn{3}{|c|}{ Disturbed } & \\
\hline & & & & & Edge & Interior & Edge & Interior & Total & \\
\hline \multirow{2}{*}{ Myrcia hartwegiana (O.Berg) Kiaersk. } & leaf & discoid & green & Coccoidea (Hemiptera) & & & & $1^{\mathrm{F}}$ & 1 & $2 \mathrm{~T}$ \\
\hline & bud & globoid $^{1}$ & brown & Cecidomyiidae & & & & $1^{\mathrm{F}}$ & 1 & $2 \mathrm{U}$ \\
\hline Myrcia palustris DC. & leaf & discoid & green/yellow & Coccoidea (Hemiptera) & & & & $1^{\mathrm{F}}$ & 1 & $3 \mathrm{~A}$ \\
\hline Myrcia retorta Cambess. & bud & fusiform $^{1,2}$ & green & Lasiopteridi (Cecidomyiidae) & $1^{\mathrm{F}}$ & 10 & 8 & 10 & 29 & 3B \\
\hline \multirow[t]{4}{*}{ Siphoneugena reitzii D.Legrand } & stem & globoid & brown & Cecidomyiidae & $1^{\mathrm{P}}$ & 9 & 4 & 7 & 10 & $3 \mathrm{C}$ \\
\hline & leaf & cylindrical & green/red & Holopothrips sp. 2 (Thysanoptera) & $1^{\mathrm{P}}$ & & & & 1 & $3 \mathrm{D}$ \\
\hline & leaf & cylindrical & green/yellow & Cecidomyiidae & & $1^{\mathrm{F}}$ & & & 1 & $3 \mathrm{E}$ \\
\hline & bud & conical & green & Cecidomyiidae & & & 8 & 8 & 16 & $3 \mathrm{~F}$ \\
\hline \multicolumn{11}{|l|}{ Podocarpaceae } \\
\hline Podocarpus lambertii Klotzsch ex Endl. & stem & fusiform & brown & Cecidomyiidae & 3 & & 3 & & 6 & $3 \mathrm{G}$ \\
\hline \multicolumn{11}{|l|}{ Primulaceae } \\
\hline $\begin{array}{l}\text { Myrsine coriacea (Sw.) R.Br. ex Roem. } \\
\text { \& Schult. }\end{array}$ & stem & fusiform & green & Lepidoptera & 3 & $1^{\mathrm{P}}$ & $2^{\mathrm{F}}$ & & 6 & $3 \mathrm{H}$ \\
\hline Myrsine lorentziana (Mez) Arechav. & stem & fusiform & green $/$ red & Lepidoptera & 9 & 10 & 3 & 2 & 24 & $3 \mathrm{I}$ \\
\hline \multicolumn{11}{|l|}{ Proteaceae } \\
\hline \multirow[t]{2}{*}{ Roupala montana Aubl. } & leaf & discoid & green/brown & Unidentified & $1^{\mathrm{P}}$ & & & & 1 & $3 \mathrm{~J}$ \\
\hline & stem & fusiform $^{2}$ & brown & Unidentified & $1^{\mathrm{P}}$ & & & & 1 & $3 \mathrm{~K}$ \\
\hline \multicolumn{11}{|l|}{ Rosaceae } \\
\hline Rubus erythrocladus Mart. & stem & fusiform $^{1,2}$ & green/brown & Unidentified & & & 2 & & 2 & $3 \mathrm{~L}$ \\
\hline \multicolumn{11}{|l|}{ Rubiaceae } \\
\hline Rudgea parquioides (Cham.) Müll.Arg. & leaf & discoid & green & Cecidomyiidae & & 6 & $2^{\mathrm{F}}$ & 9 & 17 & $3 \mathrm{M}$ \\
\hline \multicolumn{11}{|l|}{ Sapindaceae } \\
\hline $\begin{array}{l}\text { Allophylus edulis (A.St.-Hil. et al.) } \\
\text { Hieron. ex Niederl. }\end{array}$ & stem & fusiform & green & Lepidoptera & & $1^{\mathrm{F}}$ & & & 1 & $3 \mathrm{~N}$ \\
\hline \multicolumn{11}{|l|}{ Solanaceae } \\
\hline Solanum sp. L. & leaf & $\operatorname{discoid}^{1}$ & green & Unidentified & & $1^{\mathrm{P}}$ & & & 1 & 30 \\
\hline
\end{tabular}

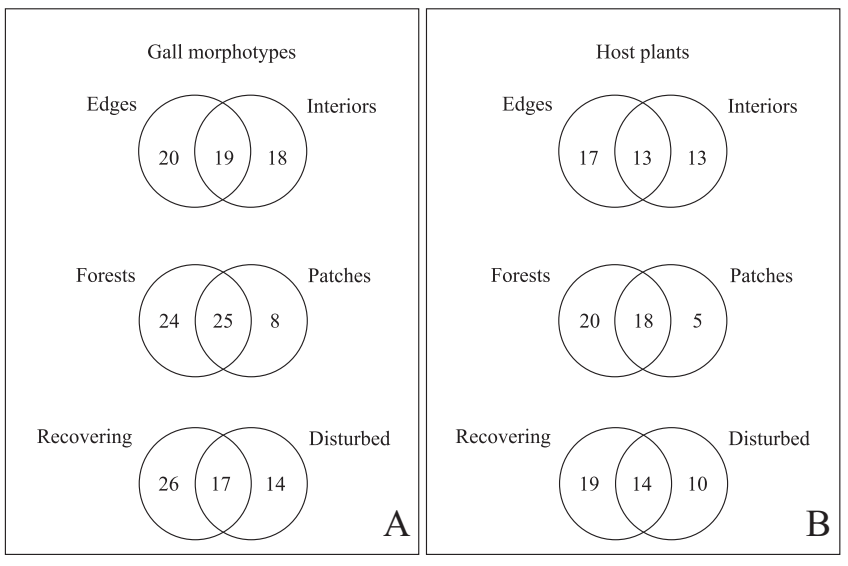

Fig. 4. Total numbers of gall morphotypes and host plants occurrence by habitat (edge and interior), forest type (continuous forests and patches) and type of disturbance (recovering and disturbed). A) Venn diagrams of the gall morphotypes, B) Venn diagrams of the host plants.

geographic trend and its ecological and evolutionary implications, which we consider worthy of further studies.

The predominance of glabrous galls has been widely reported. For instance, glabrous plants of the species Arbutus xalapensis (Ericaceae) had higher density of gallers compared to the hairy conspecifics (Ezcurra et al. 1987). Considering gall occurrence, isolated galls were more frequent, as reported by other studies. Fernandes et al. (1988) hypothesized that galls which occur isolated would be favored because parasitoid pressure would be diminished due to the greater searching time implied by isolation.

The two host plant families with more gall morphotypes, Myrtaceae and Asteraceae, figure as important taxa in other vegetation types in southern Brazil (Mendonça 2007; Mendonça et al. 2010), and even in other ecosystems throughout Brazil, as the cerrado (Gonçalves-Alvim \& Fernandes 2001), rupestrian fields (Maia \& Fernandes 2004) and restinga coastal forests (Maia et al. 2008). These two families are reported as very representative in the Araucaria forest, Myrtaceae among trees (Rambo 1956) and Asteraceae among non-arboreal species (Behling \& Pillar 2007). The importance of Melastomataceae, ranked as the third most representative host family, and also an important plant family in Araucaria forests (Machado 2004), is not widespread, being more rarely found in Atlantic forest remnants (Fernandes et al. 2001) and in the Amazon forest (Almada \& Fernandes 2011), despite being for a long time ranked as one of the richest in zoocecidea, along with the other two families (Houard 1933). Fabaceae hosted only one gall species in our study; it usually ranks high in most of the above cited gall inventories. This has been already pointed out by Mendonça (2007) based on another study conducted in south- 
ern Brazil, a pattern derived perhaps from a lack of legume plants in Araucaria forest relative to other Atlantic forest formations (Jarenkow \& Waechter 2001).

At the genus level, Myrcia also appeared in another study as the most representative genus (Maia et al. 2008), but not Myrceugenia or Siphoneugena. The genera Mikania and Eugenia, accounting respectively for only two and a single gall species, were the genera with highest number of galls in another study in an area of Atlantic forest relatively close to our study sites, while Myrcia had only three galls and Myrceugenia and Siphoneugena did not have any (Mendonça 2007). This difference might reflect the absence of host species but also differences in these genera contribution to the flora of the region. For example, the genera Myrcia and Myrceugenia are very representative to the Araucaria forest (Behling \& Pillar 2007). The presence of "super-hosts" belonging to the most representative family and genera was expected (Mendonça 2007) but even Myrtaceae with Siphoneugena reitzii and Myrcia guianensis had relatively low numbers of gall species.

This first report on the diversity of gall inducing insects from Araucaria forests constitutes an important contribution to the taxonomic knowledge of this group in the Neotropics. In general, gall characteristics follow trends already reported for the Neotropics and worldwide, sometimes more similar to studies performed in nearby ecosystems, probably reflecting a spatial correlation in a larger, biogeographical scale. We encourage more studies of gall-inducing insects in Araucaria forests in order to provide us with a clearer view of its biodiversity.

\section{ACKNOWLEDGEMENTS}

We would like to thank Valéria Maia and Adriano Cavalleri for the identification of the gall inducers; Sandra Hartz, Sheila Fernandes, Leandro Duarte and Marco Antônio Carneiro for a careful first reading of the manuscript; and PUC-RS for logistic support. This study was partially supported by CAPES.

\section{REFERENCES}

Almada, E.D. \& Fernandes, G.W. 2011. Insetos indutores de galhas em florestas de terra firme e em reflorestamentos com espécies nativas na Amazônia Oriental, Pará, Brasil. Boletim do Museu Paraense Emílio Goeldi, Ciências Naturais, 6: 163-196.

Araújo, W.S., Santos, B.B. \& Gomes-Klein, V.L. 2011. Insect galls from Serra dos Pireneus, GO, Brazil. Biota Neotropica 11: 357-365.

Behling, H. \& Pillar, V.D. 2007. Late Quaternary vegetation, biodiversity and fire dynamics on the southern Brazilian highland and their implication for conservation and management of modern Araucaria forest and grassland ecosystems. Philosophical Transactions of the Royal Society B 362: 243-251.

Carneiro, M.A.A., Branco, C.S.A., Braga, C.E.D., Almada, E., Costa, M.B.M., Fernandes, G.W. \& Maia, V.C. 2009a. Are gall midge species (Diptera, Cecidomyiidae) host plant specialists? Revista Brasileira de Entomologia 53: 365-378.

Carneiro, M.A.A., Borges, R.A.X., Araújo, A.P.A. \& Fernandes, G.W. 2009b. Insetos indutores de galhas da porção sul da Cadeia do Espinhaço, Minas Gerais, Brasil. Revista Brasileira de Entomologia 53: 570-592.
Dalbem, R.V. \& Mendonça, M.S. 2006. Diversity of galling arthropods and host plants in a subtropical forest of Porto Alegre, Southern Brazil. Neotropical Entomology 35: 616-624.

Dreger-Jauffret, F. \& Shorthouse, J.D. 1992. Diversity of gall-inducing insects and their galls, p. 8-33. In: Shorthouse, J.D. \& Rohfritsch, O. (eds.). Biology of insect-induced galls. New York, Oxford University Press, $\mathrm{xi}+285 \mathrm{p}$.

Espírito-Santo, M.M. \& Fernandes, G.W. 2007. How many species of gallinducing insects are there on earth, and where are they? Annals of the Entomological Society of America 100: 95-99.

Ezcurra, E., Gomez, J.C. \& Becerra, J. 1987. Diverging patterns of host use by phytophagous insects in relation to leaf pubescence in Arbutus xalapensis (Ericaceae). Oecologia 72: 479-80.

Fernandes, G.W., Tameirão-Neto, E. \& Martins, R.P. 1988. Ocorrência e caracterização de galhas entomógenas na vegetação do campus Pampulha da Universidade Federal de Minas Gerais. Revista Brasileira de Zoologia 5: 11-29.

Fernandes, G.W., Julião, G.R., Araújo, R.C., Araújo, S.C., Lombardi, J.A., Negreiros, D. \& Carneiro, M.A.A. 2001. Distribution and morphology of insect galls of the Rio Doce Valley, Brasil. Naturalia 26: 211-244.

Gagné, R.J. 2010. Update for a catalog of the Cecidomyiidae (Diptera) of the world. Available at: http://www.ars.usda.gov/SP2UserFiles/Place/ 12754100/Gagne_2010_World_Catalog_Cecidomyiidae.pdf(accessed 19 January 2012).

Gonçalves-Alvim, S.J. \& Fernandes, G.W. 2001. Biodiversity of galling insects: historical, community and habitat effect in four neotropical savannas. Biodiversity and Conservation 10: 79-98.

Hijmans, R.J., Cameron, S.E., Parra, J.L., Jones, P.G. \& Jarvis, A. 2005. Very high resolution interpolated climate surfaces for global land areas. International Journal of Climatology 25: 1965-1978.

Houard, C. 1933. Les Zoocécidies dês plantes de l'Amérique du Sud et de l'Amérique Central. Paris, Hermann et Cie, 519 p.

Jarenkow, J.A. \& Waechter, J.L. 2001. Composição, estrutura e relações florísticas do componente arbóreo de uma floresta estacional no Rio Grande do Sul, Brasil. Revista Brasileira de Botânica 24: 263-272.

Julião, G.R., Amaral, M.E.C., Fernandes, G.W. \& Oliveira, E.G. 2004. Edge effect and species-area relationships in the gall-forming insect fauna of natural forest patches in the Brazilian Pantanal. Biodiversity and Conservation 13: 2055-2066.

Kieffer, J.J. 1913. Diptera fam. Cecidomyiidae. Genera Insectorum 152: 1-346.

Machado, R.E. 2004. Padrões vegetacionais em capões de Floresta com Araucária no Planalto Nordeste do Rio Grande do Sul, Brasil. M.Sc. Dissertation, Universidade Federal do Rio Grande do Sul.

Maia, V.C., Mendonça, M.S. \& Romanowski, H.P. 1996. Eugeniamyia dispar gen.n. and sp. nov. (Diptera, Cecidomyiidae, Lasiopteridi) associated with Eugenia uniflora L. (Myrtaceae) in Brazil. Revista Brasileira de Zoologia 13: 1087-1090.

Maia, V.C. \& Fernandes, G.W. 2004. Insect galls from Serra de São José (Tiradentes, Minas Gerais, Brazil). Brazilian Journal Biology 64: 423-445.

Maia, V.C., Magenta, M.A.G. \& Martins, S.E. 2008. Ocorrência e caracterização de galhas de insetos em áreas de restinga de Bertioga (São Paulo, Brasil). Biota Neotropica 8: 167-197.

Maia, V.C., Zart, M. \& Botton, M. 2009. Neolasioptera ramicola, a new species of Cecidomyiidae (Diptera) associated with Physalis angulata (Solanaceae). Revista Brasileira de Entomologia 53: 163-165.

Mani, M.S. 1964. Ecology of Plant Galls. The Hague, Junk, xii+434 p.

Mendonça, M.S. 2007. Plant diversity and galling arthropod diversity searching for taxonomic patterns in an animal-plant interaction in the neotropics. Boletín de la Sociedad Argentina Botánica 42: 347-357.

Mendonça, M.S., Piccardi, H.M.F., Jahnke, S.M. \& Dalbem, R.V. 2010. Galling arthropod diversity in adjacent swamp forests and restinga vegetation in Rio Grande do Sul, Brazil. Neotropical Entomology 39: 513-518.

Moreno, J.A. 1961. Clima do Rio Grande do Sul. Porto Alegre, Secretaria da Agricultura do RS, $41 \mathrm{p}$.

Moreira, R.G., Fernandes, G.W., Almada, E.D. \& Santos, J.C. 2007. Galling insects as bioindicators of land restoration in an area of Brazilian Atlantic Forest. Lundiana 8: 107-112 
Oliveira, J.C. \& Maia, V.C. 2005. Ocorrência e caracterização de galhas de insetos na restinga de Grumari (Rio de Janeiro, RJ, Brasil). Arquivos do Museu Nacional 63: 669-675.

Oliveira, J.M. \& Pillar, V.D. 2004. Vegetation dynamics on mosaics of Campos and Araucaria forest between 1974 and 1999 in Southern Brazil. Community Ecology 5: 197-202.

Oliveira-Filho, A.T. \& Fontes, M.A.L. 2000. Patterns of floristic differentiation among Atlantic Forests in Southeastern Brazil and the influence of climate. Biotropica 32: 793-810.

Rambo, B. 1956. A flora fanerogâmica dos aparados rio-grandenses. Sellowia 7: 235-298.

Ribeiro, M.C., Metzger, J.P., Martensen, A.C., Ponzoni, F.J. \& Hirota, M.M. 2009. The Brazilian Atlantic Forest: How much is left, and how is the remaining forest distributed? Implications for conservation. Biological Conservation 142: 1141-1153.
Santos, J.C., Almeida-Cortez, J.S. \& Fernandes, G.W. 2011. Richness of gall-inducing insects in the tropical dry forest (caatinga) of Pernambuco. Revista Brasileira de Entomologia 55: 45-54.

Shorthouse, J.D., Wool, D. \& Raman, A. 2005. Gall-inducing insects - nature's most sophisticated herbivores. Basic and Applied Ecology 6: 407-411.

Tavares, J.S. 1906. Descripção de uma cecidomyia nova do Brazil, pertencente a um genero novo. Brotéria 5: 81-84.

Tavares, J.S. 1909. Contributio prima ad cognitionem cecidologiae braziliae. Brotéria 8: 5-28.

Urso-Guimarães, M.V. \& Scareli-Santos, C. 2006. Galls and gall makers in plants from the Pé-de-Gigante Cerrado reserve, Santa Rita do Passa Quatro, SP, Brazil. Brazilian Journal of Biology 66: 357-369.

Veldtman, R. \& McGeoch, M.A. 2003. Gall-forming insect species richness along a non-scleromorphic vegetation rainfall gradient in South Africa: the importance of plant community composition. Austral Ecology 28: 1-13. 